\title{
ARCHITEKTURA I WYSTRÓJ EREMÓW KAMEDULSKICH W ŚWIETLE PRAWODAWSTWA ZAKONNEGO
}

Zakon Kamedułów powstał po 1012 roku w wyniku jednej z reform zakonu benedyktyńskiego, której inicjatorem był św. Romuald z Rawenny. Nowo powstały zakon zatwierdzony został w 1072 roku przez papieża Aleksander II. Na początku XIV wieku kolejna reforma spowodowała wyodrębnienie się ze wspólnoty kamedułów nowej kongregacji o charakterze mniszym. Istotną reformę, mająca na celu powrót do ścisłej obserwacji pustelniczej, przeprowadził w 1520 roku Piotr Justiniani dając podwaliny obecnie najliczniejszej Kongregacji Pustelników Kamedułów Góry Koronnej. Wszystkie eremy kamedulskie fundowane i zakładane na ziemiach polskich od XVII wieku należały właśnie do tej Kongregacji ${ }^{1}$.

Niemal od początku swego istnienia kameduli wykształcili pewien zauważalny styl w sztuce, charakterystyczny dla wznoszonych przezeń eremów, w których konkretnym zasadom podlegała nie tylko sama architektura świątyni i klasztoru, ale i wyposażenie wnętrza, malarstwo, rzeźba czy rzemiosło artystyczne.

\section{F UNDACJE}

Jeśli jakie nowe miejsce będzie ofiarowane Zgromadzeniu, należy je przyjąć jeśli nie będzie przeciwne Instytucyi pustelniczej (...) Przy obejmowaniu nowych miejsc trzeba zwrócić uwage na wiele okoliczności, a zwłaszcza na położenie i samotność, czy mogą być zastosowane do zwyczaju pustelniczego.

${ }^{1} \mathrm{~J} . \mathrm{K} . \mathrm{W}$ i e t z, P. B o h m a n n, Rys historyczny zgromadzeń zakonnych obojej ptci wraz z rycerskiemi zakonami i orderami państw, t. 1: Zakony męskie, Warszawa 1848, s. 176-180; L. Z a r e w i c z, Zakon Kamedułów jego fundacye i dziejowe wspomnienia w Polsce i Litwie, Kraków 1871, s. 7-17; G. C a c c i a m a n i, Camaldolesi, [w:] Dizionario degli istituti di perfezione, red. G. Pelliccia, G. Rocca, Roma 1974, kol. 1718-1725; Tenże, Camaldoli, [w:] tamże, kol. 1726-1727; B. Łozińs ki, Leksykon zakonów w Polsce, Warszawa 1998, s. 60-61; J. M a r e cki, Zakony w Polsce, Kraków 2000, s. 42-43; M. D a n il u k, Kameduli, [w:] Encyklopedia katolicka, t. 8, Lublin 2000, kol. 439-443; S. S c z a n i e c k i, Kameduli, [w:] Zakony benedyktyńskie w Polsce. Krótka historia, Kraków 1981, s. 103-120; Kameduli, www.kameduli.republika.pl (14 I 2006). 
Muszą miejsca owe być zwrócone na poludnie i na wschód, a nigdy na północ. Lasy powinny mieć obszerne i gęste i obfitość wody. Będzie także bardzo pożądanem, aby położenie miejsca usposabiało do pobożności i znajdowało się miedzy ludnością wierną o pobożną ${ }^{2}$.

Przyjęcie nowego miejsca i założenie nowej fundacji kamedulskiej możliwe było zgodnie $z$ tekstem Konstytucji jedynie wówczas, gdy dotychczasowy erem stawał się niewystarczający dla dużej liczby kandydatów do życia pustelniczego ${ }^{3}$. Należy zaznaczyć, że również eremy utracone kameduli mogli na nowo zają́ jedynie wtedy, gdy spełniony był ten warunek, czyli dotychczasowe miejsce stawało się zbyty ciasne. By założenie nowej fundacji mogło nastapić, warunki bytowe nowego eremu musiały być wystarczające do utrzymania przynajmniej dwunastu pustelników ${ }^{4}$.

Wytyczne dotyczące nowych fundacji potwierdzało większość dekretów kapituł generalnych. Równocześnie do objęcia lub zbudowania nowego eremu mogło dojść jedynie za zgodą kapituły generalnej. Kapituła mogła także podjąć decyzję oddania przyjętej już fundacji, gdy ustalone założenia nie zostały spełnione lub, gdy lokacja eremu z jakichś powodów przestała służyć rozwojowi duchowemu mnichów tam mieszkających. Do założenia nowego eremu konieczna była także zgoda biskupa diecezji, będąca gwarantem możliwości życia zgodnego $\mathrm{z}$ chryzmatem zakonnym. Zgoda biskupa była także niezbędna by erem mógł posiadać kościół klasztorny, zwłaszcza w wypadku, gdy miały w nim być odprawiane Msze święte dla wiernych. Należy zaznaczyć, że dość rygorystycznie przestrzegano zasad lokalizacji eremów ${ }^{5}$. Na przykład fundacja A. Giebultowskiego na Mazowszu nie został przyjęta przez kamedułów, bowiem nie odpowiadała przepisom zakonnym ${ }^{6}$.

Najstarszą fundacją na ziemiach polskich był erem na Bielanach pod Krakowem zwany eremem Srebrnej Góry ${ }^{7}$. Kameduli sprowadzeni i osadzeni tu zostali

${ }^{2}$ Reguła św. Benedykta i Konstytucye Zgromadzenia Kamedułów - Pustelników Góry Koronnej, Kraków 1912, s. 378-379.

${ }^{3}$ Konstytucje Apostolskie, Dekrety Kapitulne, [w:] Reguta św. Benedykta i Konstytucye..., s. 54-55.

${ }^{4}$ Dekret Grzegorza XV, [w:] Regula św. Benedykta i Konstytucye..., s. 378.

${ }^{5}$ Por. Konstytucje Kongregacji Pustelników Kamedutów Góry Koronnej, Kraków 1991, nr 183, 184.

${ }^{6}$ Zob. M. i M. F l o r k o w s c y, Kameduli, Kraków 2005, s. 271-272.

${ }^{7}$ Nazwa wzgórza i eremu Srebrna Góra wiąże się z pewną historią otóż teren, na którym mieli osiedlić się sprowadzeni przez Wolskiego kameduli, należał do kasztelana Lubomirskiego, który nie zamierzał odsprzedawać posiadłości. Wówczas Wolski wyprawił ucztę, na która zaprosił oprócz wielu inny znamienitych osób także kasztelana. Gdy humory zaczęly wszystkim już mocno dopisywać Wolski opowiedział publicznie o problemach lokacyjnych nowo sprowadzonego zakonu. Lubomirskiemu w takiej sytuacji nie uchodziło odmówić ofiarowania góry bielańskiej. Wolski jako znak wdzięczności podarował Lubomirskiemu srebrną zastawę, która służyła w czasie uczty - stąd nazwa wzgórza i eremu - Srebrna Góra. Por. A. M a ł k i e w i c z, Zespót architektoniczny na Bielanach pod Krakowem (1605-1630), „Zeszyty Naukowe Uniwersytetu Jagiellońskiego. Prace z historii sztuki”, nr 45, z. 1:1962, s. 145; M. i M. F l o r k o w s c y, Kameduli..., s. 47-51 (książka w dużej mierze stanowi zlepek tekstów opublikowanych wcześniej przez innych autorów np. A. Małkiewicza, nie zaznaczonych jako cytaty). 
w 1604 roku przez Mikołaja Wolskiego - marszałka koronnego ${ }^{8}$. Wolski był miłośnikiem i mecenasem sztuki i je kolekcjonowal ${ }^{9}$, fundował liczne budowle i prowadził przebudowy, które znamy jednak jedynie $z$ materiałów archiwalnych $^{10}$. Erem wzniesiony w jego dobrach na terenie Woli Justowskiej był dla Wolskiego fundacją wyjątkową bowiem dokonał jej jako akt zadośćuczynienia za swoje grzechy ${ }^{11}$. Część mieszkalna została wzniesiona w latach 1605-1609, zaś kamień węgielny pod kościół klasztorny poświęcił w 1609 roku nuncjusz apostolski Simonetta. Prace przerwano na krótko około 1617 roku, gdy zawaliła się większa część wniesionej już świątyni. Rok później kierownictwo buđowy objął architekt Andrzej Spezza, który wykonał także projekt fasady kościoła. Prace zakończono dopiero okolo 1642 roku $^{12}$. Lokalizacja eremu spelniała warunki postawione przez konstytucje zakonne ${ }^{13}$. Miejsce wybrane po budowę eremu było zalesionym wzgórzem niedaleko Krakowa. Z powodu braku dostatecznego miejsca na budowę - splantowany został wierzchołek wzgórza tak, aby mogły zostać wzniesione stosowne zabudowania ${ }^{14}$.

Kolejna fundacja na ziemiach polskich miała miejsce w 1621 roku, choć kapituła generalna wyraziła zgodę na nową fundację już w 1617 roku. Wojewoda krakowski Jan Tęczyński i jego brat Gabriel wojewoda lubelski sprowadzili mnichów do Rytwian, fundując erem zwany Pustelnią Złotego Lasu ${ }^{15}$. Założony na równinie wśród sosnowych sandomierskich lasów nad rzeką Czarny, erem w pełni zasługiwał na swoją nazwę, choć ona sama wzięła się nie tyle od piękna otaczającej erem przyrody a od przekazania przez Tęczyńskiego eremowi wielu naczyń

${ }^{8}$ Kameduli początkowo mieszkali gościnnie u benedyktynów tynieckich.

${ }^{9} \mathrm{~W}$ testamencie nakazał zniszczyć wszystkie swoje wiersze oraz ,nieskromne" obrazy ze swojej kolekcji. Biblioteka Czartoryska, sygn. 1821, Testament Wolskiego, rkps.; A. M a 1 k i e w i c z, Zespól architektoniczny..., s. 144.

${ }^{10} \mathrm{~Np}$. przebudował kościoły w Krzepicach, Kłobucku, zamek w Rabsztynie itp.

${ }^{11}$ Wolski pełniąc funkcję komandora zakonu maltańskiego czerpal z tego tytułu duże profity równocześnie nie robiąc nic na rzecz samego zakonu. Jako akt pokuty i zadośćuczynienie po spowiedzi Wolski otrzymał nakaz założenia fundacji. Wybór jego padł na kamedułów, których po wielu staraniach sprowadził do Polski. Fundator w akcie fundacyjnym zapisał kamedułom między innymi wsie Mników i Mnikówek oraz Bielany a w testamencie dodatkowo wsie Malec i Ryczówek oraz kamienicę przy ul. Gołębiej w Krakowie. Por. L. Z a r e w i c z, Zakon Kamedulów..., s. 17-31.

${ }^{12} \mathrm{~A} . \mathrm{M}$ a $\nmid \mathrm{k}$ i e w i c $\mathrm{Z}, Z$ historycznej i artystycznej problematyki kościola kamedułów na Bielanach pod Krakowem, „Zeszyty Naukowe Uniwersytetu Jagiellońskiego. Prace z Historii Sztuki", nr 10:1972, s. 83-107.

${ }^{13}$ Por. Reguta św. Benedykta i Konstytucye..., s. 378-379.

${ }^{14}$ A. M a $1 \mathrm{k}$ i e w i c z, Zespól architektoniczny..., s. 148; tenże, Z historii i artystycznej..., s. 83-107; S. T o m k ow i c z, Bietany, „Biblioteka Krakowska”, nr 26:1904, s. 10-13; Tenże, Bielany, [w:] Teka Grona Konserwatorów Galicji Zachodniej, t. 2, Kraków 1906, s. 6-52; W. K ret, Problematyka artystyczne kościola oo. kamedulów na Bielanach pod Krakowem. „Kwartalnik Architektoniczny i Urbanistyczny”, nr 12:1967, s. 23-55.

${ }^{15}$ Fundator zapisał jako uposażenie dla pustelników min. wieś Sieragi, Zrębin i Wolicę oraz czynsz 6000 złp z wsi Halassy i 6000 złp z Myślachowic, potem zaś połowę wsi Szczęka itd. 
liturgicznych, wśród których wyróżniała się szczerozłota puszka na komunikanty wysadzana szmaragdami i diamentami ${ }^{16}$.

Trzeci z kolei erem ufundował w 1641 roku król Władysław IV jako wotum za otrzymanie korony polskiej i za zwycięstwo nad Moskwą i Turcją ${ }^{17}$. Z powodu osoby fundatora Bielany warszawskie zaczęto nazywać Górą Królewską. Sam erem usytuowany jest na niewielkim wzgórzu wśród lasu nad brzegiem Wisły zdecydowanie jest to miejsce usposabiajace do pobożności $i^{18}$.

Lokacja w Bieniszewie zwana Eremem Pięciu Braci Męczenników powstała staraniem samych kamedułów krakowskich w 1663 roku. Na osiedlenie mnichów w miejscu zamordowania pięciu braci uważanych za pierwszych kamedułów na ziemiach polskich: Benedykta, Jana, Krystyna, Izaaka i Mateusza, przeznaczył swoje dobra Albert Kadzidłowski właściciel wsi Bieniszew. Erem wybudowano na wzgórzu zwanym Sowią Górą pośród dębowego lasu nieopodal jeziora Skape. Na skutek hojnego obdarowania kamedułów przez Kadzidłowskiego, nie brakowalo mnichom drewna budulcowego $\mathrm{z}$ pobliskiego lasu ani ryb $\mathrm{z}$ jeziora. Lokalizacja także tego eremu spełniała założenia ustawodawcze i przepisy zakonne ${ }^{19}$.

Rok później Krzysztof Zygmunt Pac kanclerz litewski, ufundował erem kamedulski w Pożajściu - miejscowości oddalonej 8 kilometrów od Kowna. Erem ten zyskał nazwę Góry Pokoju - Monte Pacis, co dało z czasem nazwę - Góra Pacowska, bardziej kojarząca się z nazwiskiem fundatora niż z pokojem. Była to pierwsza i jedyna fundacja kamedułów na ziemi litewskiej ${ }^{20}$.

Kolejną fundacją królewską był erem w Wigrach zwany Eremem Wyspy Wigierskiej, choć z czasem mnisi połączyli wyspę z lądem tworząc półwysep, co wydatnie ułatwiło pustelnikom komunikację chociaż zadało kłam nazwie eremu. Środki na wybudowanie pustelni i kościoła oraz na utrzymanie pustelników wyłożył Jan Kazimierz. Erem miał być wotum dla Boga - w ten sposób Jan Kazimierz

${ }^{16}$ L. Z a rew i c z, Zakon Kamedulów..., s. 31-35; J. Z u b, Rytwiany. Pustelnia kamedulska, Tarnobrzeg 1995, passim; Pustelnia Ztotego Lasu w Rytwianach, Rytwiany 2003, passim; M. B rykowska, Wartości architektoniczno-przestrzenne zespotu kamedulskiego Eremus Silwae Aureae w Rytwianach, [w:] Idźcie do źródla, red. W. Kowalewski, Rytwiany 2001, s. 39-58; Taż, Pustelnia Zlotego Lasu, [w:] Sztuka około roku 1600, Warszawa 1974, s. 225-246; M. i M. F 1 o r k o w s c y, Kameduli..., s. 270-280.

${ }^{17}$ Król Władysław IV uposażając erem przekazał na jego utrzymanie młyn Ruda z przynależnościami oraz wieś Polków. Kameduli mieli także prawo połowu ryb w Wiśle i prawo do wyrębu lasu.

${ }^{18}$ M. i M. F 1 or k ow s c y, Kameduli..., s. 285-299; L. Z a re w i c z, Zakon Kamedutów..., s. 35-38.; J. Z i e l iń sk i, Bielany. Przewodnik historyczno-sentymentalny, Warszawa 2003, passim; M. B r y k ow s k a, Kościót Kamedulów na Bielanach. Warszawa 1982, passim; Taz, Zespót architektoniczny pustelni kamedulskiej na warszawskich Bielanach, [w:] Las Bielanski, rezerwat przyrodniczy w Warszawie, red. T. Baum, P. Trojan, Warszawa 1982, s. 42-64.

${ }^{19}$ L. Z a r e w i c z, Zakon Kamedulów..., s. 38-40; S. Paszek, L. R u t e c k i, Pustelnia bieniszewska. Zarys dziejów, Konin 2000, passim; M. i M. Flork ow s c y, Kameduli.., s. 307-319; A. S z y m a ń s k i, Trzysta lat eremu kamedułów w Bieniszewie, „Przewodnik Katolicki”, nr 55:1965, s. 326-327; J. U r b a n, 50-lecie powrotu ojców kamedulów do pustelni „Srebrna Góra” w Bieniszewie, „Życie i Myśl”, nr 35:1987, z. 9-10, s. 143-149.

${ }^{20}$ L. Z a r ew i c z, Zakon Kamedutów..., s. 40-46; M. i M. F J o r k ow s c y, Kameduli..., s. 325-335. 
chciał odwrócić od Polski liczne klęski ${ }^{21}$. Erem wzniesiono nad jeziorem Wigry w 1667 roku $^{22}$.

W 1722 roku margrabia Józef Władysław Myszkowski, ufundował w pobliżu miejscowości Szaniec erem kamedulski zwany Eremem Margrabskiego. Do nowego eremu przybyło pięciu mnichów spod krakowskich Bielan. Zespół klasztorny przeznaczony był dla ośmiu mnichów ( $\mathrm{z}$ ośmioma pustelniami), a więc dla mniejszej ilości kamedułów niż przewidywały to przepisy zakonne ${ }^{23}$.

Ostatnim eremem wzniesionym dla kamedułów na ziemiach polskich był klasztor w Milatynie ufundowany w 1738 roku przez Teresę z Krasińskich Gałecką miecznikową podlaską. Erem ten istniał jedynie siedem lat, bowiem na skutek zaniedbań dyscypliny zakonnej oraz z powodu trudności materialnych został rozwiązany przez wizytatora o. Klemensa Neapolitańczyka w $1745 \mathrm{roku}^{24}$.

Precyzyjne wytyczne odnoszące się do zakładania nowych fundacji kongregacji Góry Koronnej, określił już Paweł Justiniani, wzorując się na wytycznych przekazanych przez św. Romualda i zawartych w konstytucjach z 1080 roku. Kolejne przepisy określające położenie eremu oraz jego wygląd precyzowały kapituły generalne kongregacji, zwłaszcza odbywane w początku XVII wieku. Przepisy miały obowiązywać we wszystkich fundacjach kamedulskich niezależnie od kraju, w jakim były zakładane.

W procesie fundacyjnym najistotniejszą kwestią była lokalizacja. Erem musiał być położony poza obrębem miasta. Zwyczajowo miała to być mila od skupisk miejskich. W Konstytucjach przeczytać można, że

nasze eremy niech będą odległe od miejsc zamieszkałych i oddalone co najmniej o dwa kilometry od wielkich miast i osiedli, a to dla ochrony przed hałasem światowym ${ }^{25}$.

${ }^{21}$ Fundator przekazał kamedułom między innymi część puszczy Uhoł. Kolejni królowie Polski potwierdzając akt darowizny dokładali kolejne, w rezultacie klasztor ten stał się jednym z najbogatszych na ziemiach polskich. Do kamedułów należało niemal czterdzieści wsi i blisko trzydzieści jezior.

${ }^{22}$ L. Z a r ew i c z, Zakon Kamedulów..., s. 47 - 50; S. M a ci e jew s k i, Opowieści o kamedulach wigierskich, Suwałki 1999, passim; Tenże, Pokamedulski zespół klasztorny Wigry, Suwałki 2000, passim; M. i M. F l o rk ow s c y, Kameduli..., s. 336-345; M. A m b r o z i e w i c z, Zespól Pokamedulski w Wigrach, Suwałki 1998, passim; J. U rb a n, 320-lecie fundacji pustelni ojców kamedulów w Wigrach. „Życie i Myśl”, nr 35:1987, z. 11-12, s. 141-145; W. K o c h a n o w s k i, Architektura zespotu pokamedulskiego w Wigrach. [w:] Studia i Materiaty do dziejów Suwalszczyzny, Białystok 1965, s. 139-174.

${ }^{23}$ L. Z a r e w i c z, Erem Margrabski oo. Kamedułów w Szańcu, b.m. 1879, passim; Tenże, Zakon Kamedulów..., s. 50-53; M. i M. F l o r k ow s c y, Kameduli..., s. 346-353.

${ }^{24}$ D. Now a c k i, Kościót p.w. Św. Krzyża i dom zakonny (plebania)w Milatynie Nowym, w: Materiaty do dziejów sztuki sakralnej na ziemiach wschodnich dawnej Rzeczypospolitej, cz. 1: Kościoły i klasztory rzymskokatolickie dawnego województwa ruskiego, red. J. K. Ostrowski, t. 4. Kraków 1996, s. 65; P. B r u k w i c k i, Z Milatyna Nowego, „Rocznik Obydwóch Zgromadzeń Św. Wincentego a Paulo", nr 17:1911, s. 189-197; M. i M. F l o r k o w s c y, Kameduli..., s. $351-353$.

${ }^{25}$ Konstytucje Kongregacji Pustelników..., s. 61. 
Najlepszym miejscem na założenie nowego eremu były wzgórza. Praktyka ta stosowana była w zakonie kamedulskim już od XI wieku. Góra bowiem jest symbolem dążenia do bliskości z Bogiem, a równocześnie trudno dostępne zbocze wzgórza sprzyja oderwaniu się od świata zewnętrznego. Zwyczaj ten jednak nie zawsze był przestrzegany, a to $\mathrm{z}$ powodu rozprzestrzeniania się zakonu kamedułów i zakładania nowych eremów także na nizinach oraz na terenach pozbawionych jakichkolwiek wzgórz ${ }^{26}$.

Eremy zgodnie z tekstem konstytucji budowano pośród lasów.

Pustelnie nasze mają być między gęstymi lasami, które sadzeniem, szczepieniem, obcinaniem i wszystkimi możliwymi sposobami niech się zachowuje i pomnaża 27 .

Umiejscowienie eremu w lesie miało nie tylko pomóc w odizolowaniu od świata, ale i symbolizować puszczę. Jednak z przyczyn oczywistych częściowo należało splantować terenem (co stawało się w rezultacie symbolem pustyni). Jednak proceder wycinania drzew był bardzo rygorystycznie kontrolowany. W rozdziale I reguły czytamy:

i dlatego w obrębie Eremu drzewa ściąć nie wolno, aby nie zniszczyć piękności miejsca; a kto bez pozwolenia Przeora wytnie jakieś zielone drzewo, za kaźde ma pościć raz o chlebie i wodzie; a jeżeliby zaś Przeor miejscowy bez zezwolenia Kapituły domu nakazał cięcie drzewa w klauzurze Eremu, niech będzie ukarany dyscypliną cyrkularną od Ojców Wizytatorów lub Kapituły Generalnej, co się rozumie, jeśli cięcie przechodzi liczbę 4 lub 5 drzew i to przez cały czas jego przeorstwa, co się nie powinno robić bez słusznych przyczyn, wyjąwszy gdyby drzewa takowe szpeciły piękność miejsca ${ }^{28}$.

W późniejszych dekretach kapitulnych posunięto się jeszcze dalej zabraniając nie tylko wycinania drzew, ale nawet obcinania gałęzi. Motywowano to tym,

aby były zachowane drzewa $\mathrm{i}$ ich gałęzie, które robią cień albo piękny widok wzdhuż drogi (...) zakazując każdemu Przełożon. lub Rządcy pod karą złożenia (...) którzy by bez pozwolenia Kapituły Generalnej niszczyli lub wycinali jaka $\mathrm{z}$ wymienionych roślin ${ }^{29}$.

Dalej dekret wspomina o zakazie plantowania lasów bez wyraźnej potrzeby. Eremy budowano tak, aby zapewnić sobie moźliwie latwy dostęp do wody rzeki lub jeziora. Kameduli, podobnie jak inni mnisi reguły benedyktyńskiej, nie jedli mięsa, używali natomiast w swojej diecie ryb. W Regule św. Benedykta czytamy:

Wszyscy zaś mają bezwzględnie powstrzymać się od jedzenia mięsa zwierząt czworonożnych ${ }^{30}$.

${ }^{26}$ M. B r y k ow s k a , Pustelnia Zlotego Lasu..., s. 226.

${ }^{27}$ Regula św. Benedykta i Konstytucye..., s. 13.

28 Tamże.

${ }^{29}$ Zbiór Konstytucyj Apostolskich i Dekretów Kapitulnych, [w:] Reguta św. Benedykta i Konstytucye..., s. 39

${ }^{30} \mathrm{G}$. H o l z h e r r, Reguła benedyktyńska w życiu chrześsijańskim, Tyniec 1988, s. 164. 


\section{Konstytucje zaś dodają, że}

pod nazwą zwierząt czworonożnych w tem miejscu, nie ma wątpliwości, że i mięso zwierząt dwunożnych jest objęte ${ }^{31}$.

Dozwolone było przez Konstytucje natomiast spożywanie rosołu. Nakaz spożywania jedynie mięsa rybiego w eremach kamedulskich opisuję, w dość zabawny dla współczesnego czytelnika sposób Jędrzej Kitowicz:

Kaczki dzikie, nurkami i łysicami zwane, także bobry, wydry i żółwie jedzą za ryby, ponieważ te zwierzęta, według naturalistów, mają więcej przyrodzenia wodnego niż ziemnego ${ }^{32}$.

Topograficzne usytuowanie eremu nie było tak rygorystyczne. Nie wszędzie są góry, zatem dopuszczano pewne niewielkie odstępstwa. Zresztą już eremy włoskie wykazywały w tej mierze różnorodność. Na przykład w Monte Corona lub w Monte Rua pustelnie są zbudowane na zboczu wzgórza a kościół i ogrody poniżej. W eremie neapolitańskim ermitorium zbudowano za kościołem, niejako na osi świątyni. Eremy polskie budowane w sposób bliższy eremowi neapolitańskiemu posiadaja układ symetryczny, różniąc się pomiędzy sobą jedynie drobnymi elementami typu przejście do ogrodów z ermitorium, dodatkową wieżą lub dodatkową przestrzenia pomiędzy pustelniami. Zaznaczyć jednak należy, że fundacje polskie posiadały nieco odmienny charakter od kamandoli włoskich, wyróżniając się większym rozmachem, odmiennymi rozwiązaniami (niejednokrotnie narzuconymi przez fundatora, jednak będącymi do zaakceptowania przez generalna kapitułę) oraz znacznie bogatszym wystrojem świątyń.

\section{K L A S Z TOR}

Pierwsze klasztory kamedulskie posiadały swoisty charakter, odzwierciedlający dwutorową formację mnichów. Klasztor dzielił się na część zewnętrzną ze świątynią klasztorną cenobitów i domem gościnnym oraz na część „wewnętrzną" - czyli domki pustelnicze dla eremitów, które otaczał mur. Pustelnie najczęściej usytuowane były z dala od klasztoru, w górach, wśród lasu, tak by dostęp do pustelników był możliwie jak najbardziej ograniczony, by nic nie zakłócało im modlitwy i skupienia. Ogólny podział klasztoru na dwie części od samego początku nie był jednak rygorystycznie przestrzegany ${ }^{33}$.

Odmienna sytuacja miała miejsce w Kongregacji Góry Koronnej. Od początku XVII wieku eremy budowane były według precyzyjnie określonych zasad. Przepisy budowlane eremów kamedulskich ostatecznie zatwierdzono i usystematyzowano na kapitułach generalnych w latach $1607,1608 \mathrm{i} 1610$. Ustalenia te miały stworzyć wytyczne pozwalające na ujednolicenie formy architektonicznej

${ }^{31}$ Regula św. Benedykta i Konstytucye..., s. 185.

${ }^{32} \mathrm{~J}$. K i t o w i c z, Opis abyczajów za panowania Augusta III, Warszawa 1985, s. 90.

${ }^{33}$ J. G a je w s k i, Kameduli. Sztuka, [w:] Encyklopedia katolicka, t. 8, Lublin 2000, kol. $443-446$. 
eremów kongregacji tak, aby pozostawały w zgodzie z tradycją i charakterem zakonu. Uchwały stanowczo i rygorystycznie określały schemat budowy zarówno kościoła jak i całego eremu. Obowiązywać miały we wszystkich krajach, w których wznoszono klasztory kamedulskie. O stanowczości i rygorystycznym narzuceniu wytycznych świadczyć może fakt, że przepisy należało zastosować także w tych eremach, które w chwili uchwalenia przepisów były już w trakcie budowy, mimo że wcześniejsze plany uzyskały zatwierdzenie i aprobatę. Dodać należy, że każdy plan nowo wznoszonego eremu musiał uzyskać akceptację kapituły generalnej, która stwierdzała zgodność projektu z prawem zakonnym ${ }^{34}$.

Eremy kamedułów Kongregacji Góry Koronnej, podobnie jak pierwotne klasztory kamedulskie miały mieć podział na dwie, obwiedzione wspólnym murem, części. Pierwsza z nich obejmowała kościół i klasztor. W tej części mogli przebywać mężczyźni: świeccy lub duchowni (nie kameduli) a nawet w określone dni roku - kobiety. Drugą część - wewnętrzną - otoczoną drugim dodatkowym murem stanowiły pustelnie, w których zamieszkiwali mnisi. W tej części znajdowały się także pomieszczenia dla nowicjuszy. W części wewnętrznej eremu nie mogli zamieszkiwać natomiast bracia laicy. Obowiązywał tam także bezwzględny zakaz wstępu osób z poza zakonu ${ }^{35}$.

Ermitorium składało się z kilku lub kilkudziesięciu pustelni wybudowanych w równoległych szeregach przedzielonych alejkami. W Konstytucjach zaznaczono, że

cele nie mają być połączone ze soba, lecz o ile na to miejsce pozwoli, powinny być oddalone od siebie mniej więcej 30 stóp $^{36}$.

Pustelnie miały, zgodnie z przepisami, posiadać co najwyżej cztery pomieszczenia: kaplicę, celę, pomieszczenie gospodarcze i pomieszczenie sanitarne. Przed wejściem do domku pustelniczego znajdował się niewielki ogródek, w którym kameduła uprawiał, na przykład, kwiaty lub zioła ${ }^{37}$. Każdą pustelnię otaczać miał dość wysoki mur. Jedyna jego brama wychodziła bezpośrednio na aleję ermitorium. Konstytucje dość lapidarnie wspominaja, że

cele dla Rekluzów będą przeznaczone te, które są więcej od innych oddalone, które mają swoją kapliczkę z ołtarzem (...) i ogródki okolone murem ${ }^{38}$.

Jednak wytyczne architektury eremów sprecyzowały bardzo dokładnie ustalenia kapituły generalnej z 1607 roku. Akta kapitulne potwierdziły zwyczaj budowania pustelni posiadających co najwyżej cztery pomieszczenia, z których jedynie kaplica, cela i korytarzyk mogły być sklepione, jednak nie można było zastosować jakichkolwiek gzymsów polichromii czy innych zdobień. Do pustelni miało się wchođzić po dwóch stopniach. W celi mieszkalnej miały być otwory w ścianie

${ }^{34}$ A. M a l k i e w i c z, Z historycznej i artystycznej..., s. 96.

${ }^{35}$ J. G a je w s k i, Kameduli. Sztuka..., kol. 444.

${ }^{36}$ Reguta św. Benedykta i Konstytucye..., s. 14.

${ }^{37}$ W ogródku przy pustelni można było uprawiać także warzywa, jednak mnich nie mógł ich sam spożywać. Mógł natomiast sporządzać dla siebie jedynie sałatkę z ziół.

${ }^{38}$ Reguta św. Benedykta i Konstytucye..., s. 20. 
przeznaczone na naczynia oraz kominek i łóżko nad ziemią około 2,5 stopy. Okna miały być usytuowane na tyle wysoko, by zerknięcie do wnętrza celi było utrudnione. Równocześnie żadne okno nie mogło wychodzić na ogródek sąsiadującej pustelni ${ }^{39}$.

Układ pustelni charakteryzujący się ułożeniem domków eremickich w równoległych szeregach występuje we wszystkich eremach na ziemiach polskich. W eremie Srebrnej Góry podobnie jak i w podwarszawskim oraz w Rytwianach pustelnie ułożono w czterech rzędach, przy czym w eremie podkrakowskim było ich 20 (po pięć domków w każdym rzędzie), w eremie na Bielanach podwarszawskich w czterech rzędach umieszczono trzynaście domków, zaś w Rytwianach było ich $\mathrm{w}$ rezultacie $16^{40}$. W eremach wigierskim, szanieckim i bieniszewskim pustelnie ułożono w dwóch rzędach ze względu na mniejsza ich liczbę. W Wigrach było ich dziesięć, zaś w Szańcu osiem ${ }^{41}$.

Pustelnie i klasztor miały być otoczone ogrodami i sadami. Do zabudowań eremu należały także między innymi: piekarnia, pasieka, browar, gorzelnia, kurnik (w eremie podkrakowskim hodowano do $200 \mathrm{kur}$ ), stajnie dla bydła oraz stodoły a nawet apteki (np. w Wigrach i w Rytwianach). Wszystko to miał otaczać mur klasztorny, przy czym przepisy określające konieczność wznoszenia murów zatwierdziła dopiero kapituła generalna w 1670 roku $^{42}$. W Konstytucjach czytamy natomiast, że

zabudowania nasze powinny być otoczone na około płotem, rowem lub murem tak, aby się tam nie wchodziło jak tylko przez bramkę ${ }^{43}$.

W wypadku eremów budowanych na wzgórzach usytuowanie ogrodów sprawiało pewną trudność. Na przykład na Bielanach podkrakowskich ogrody założono na skonstruowanych w tym celu tarasach. Niejednokrotnie sady kamedulski były imponujące. W eremie w Wigrach na początku XIX wieku rosło prawie tysiąc drzew owocowych.

\section{Ś WIAtT Y N IA}

Kościoły kamedulów posiadaly specyficzną formę. Ze względu na klauzurowy charakter zakonu praca duszpasterska nie była przewidywana, zatem cała świątynia klasztorna była przeznaczona dla mnichów, nie było zatem potrzeby wydzielania przestrzeni dla duchownych i osobnej dla wiernych.

${ }^{39}$ P. T. Lug a no, La Congregazione Camaldolese degli eremiti di Monte Corona, Rzym 1908, s. 346-347; M. B r y k ow s k a, Wartości architektoniczno-przestrzenne ..., s. 53; Taż, Pustelnia Zlotego Lasu..., s. 226-227.

${ }^{40}$ M. B r y kow sk a, Wartości architektoniczno-przestrzenne ..., s. 40; Taż, Pustelnia Zlotego Lasu..., s. 225-246.

${ }_{41}$ A. M ałk i ewi c z, Zespót architektoniczny..., s. 147 nn; J. Gajew sk i, Kościól $i$ klasztor kamedutów na Bielanach pod Krakowem w świetle materialów archiwalnych, „Biuletyn Historii Sztuki", r. 38:1976, nr 4, s. 374-377.

${ }^{42}$ M. B r y k o w s k a, Pustelnia Zlotego Lasu..., s. 225, 236.

${ }^{43}$ Reguta św. Benedykta i Konstytucye ..., s. 13-14. 
Według uchwał kapituły generalnej z początku XVII wieku kościół klasztorny powinien być wielkością zgodny z kościołem macierzystego eremu na Monte Corona $^{44}$. Odstępstwa od tej reguly akceptowane były w bardzo niewielkim stopniu, przy czym nowo wznoszona świątynia mogła być nieco mniejsza; nie dopuszczano natomiast możliwości by mógł być większy od macierzystej świątyni. Świątynia powinna być jednonawowa, chór zakonny winien sąsiadować z kapitularzem, nad którym lokalizowano bibliotekę oraz z drugiej strony z zakrystia, w której powinna ponadto mieścić się niewielka kapliczka. Na pięterku nad zakrystią umiejscowiony był skarbiec. Do nawy miały przystawać dwie kaplice. Nie przewidywano budowy większej ilości ołtarzy. W każdym pomieszczeniu lub raczej przestrzeni kościoła mógł się znajdować jedynie jeden ${ }^{45}$.

Cechą charakterystyczną kościołów kamedulskich jest wieża usytuowaną przy prezbiterium od południowej strony. Jest to element właściwie powszechnie występujący w architekturze kamedulskiej jednak nie jest usankcjonowany żadnym, przepisem w prawodawstwie zakonnym. Stanowi raczej element zwyczajowy, świadczący o zachowywanej tradycji. Niekiedy jednak (także w eremach polskich) można spotkać się z dwiema wieżami po obu stronach prezbiterium. Najczęściej przechowywano w nich archiwalia lub usytuowane były w nich biblioteki. Niejednokrotnie pełniły także funkcję wież zegarowych oraz dzwonnic ${ }^{46}$.

Najbardziej zgodny z prawodawstwem zakonnym jest kościół w Rytwianach. Jest to jednonawowa światynia $z$ silnie zarysowanym chórem zakonnym zajmujacym około 1/3 długości kościoła. Od strony południowej i północnej usytuowano kapitularz, zakrystię i po dwie kaplice komunikujące się ze świątynią. W zakrystii wydzielone zostały dwie przestrzenie: kaplica i miejsce na lavabo (lawaterz). Jedynym odstępstwem od reguł zakonnych jest bogaty wystrój wnętrza, z polichromią wykonaną przez kamedułę włoskiego Wenatego z Subiaco.

Kościoły kamedulskie na ziemiach polskich to świątynie zasadniczo odpowiadające przepisom zakonnym w kwestii architektonicznej. Najczęściej jednonawowe z nawą prostokątną (podkrakowskie Bielany, Rytwiany, Wigry, Bieniszew) lub o układzie centralnym (Bielany k. Warszawy, Pożajścic). Kościoły posiadały dwuwieżowe fasady (Pożajście, Bielany $k$. Krakowa) lub dwie wieże przylegające do prezbiterium (Wigry, Szaniec, Bieniszew, podwarszawskie Bielany). Wyjątkiem w tej mierze jest erem w Rytwianach posiadający tylko jedną wieżę przylegająca do nawy od strony południowej. Przepisy zakonne wyraźnie bowiem wskazywały na możliwość wznoszenia tylko jednej wieży przy prezbiterium tak jak to ma miejsce w Rytwianach. Polskie kościoły kamedułów posiadały jednak najczęściej więcej niż jedna wieżę (na Bielanach k. Krakowa aż trzy) co stało się cechą wyróżniającą budowle kamedulskie na ziemiach polskich.

W niektórych wypadkach na kształt i wystrój świątyń miały wpływ nie tylko przepisy zakonne ale i wola fundatorów. Na przykład kościół podkrakowski zdobią aż trzy wieże oraz sześć kaplic, bowiem zamiarem Wolskiego było wzniesie-

\footnotetext{
${ }^{44}$ Bielany pod Krakowem - $28 \mathrm{~m}$.; Rytwiany $26 \mathrm{~m}$.,

${ }^{45}$ A. M ał k i e w i c z, Zespół architektoniczny..., s. 149-153.

${ }^{46}$ A. M ałk i e w i c z, $Z$ historycznej $i$ artystycznej ..., s. 85.
} 
nie okazałej świątyni, a właściwie kompleksu świątyń ${ }^{47}$, które miały by z czasem stać się miejscem pielgrzymkowym. Wolski na budowę eremu przeznaczył zresztą ogromną sumę 500 tysięcy złotych, co także obrazuje rozmach i skalę kompleksu klasztornego ${ }^{48}$.

Warto wspomnieć o wezwaniach kościołów kamedulskich. Sześć, spośród ośmiu świątyń polskich, dedykowanych zostało Matce Bożej ${ }^{49}$. Jedynie kościół w Szańcu był pod wezwaniem św. Józefa (co poniekąd też wiąże się z kultem maryjnym) a kościól w Milatynie pod wezwaniem Krzyża Świętego.

Maryja odgrywa bardzo istotną rolę w duchowości zakonnej kamedułów. W czasie pierwszej kapituły generalnej, która odbyla się w eremie Monte Corona w 1524 roku, mnisi oddali nowopowstałą kongregację pod szczególną opiekę obierając ją Pośredniczką i Patronką. W Konstytucjach zakonnych czytamy, że

Najświętsza Dziewica Maryja, Matka Boża i nasza jest znakomitym przykładem życia kontemplacyjnego, dlatego niech nasi pustelnicy czczą Ja z prawdziwa miłością i ze specjalnym nabożeństwem także przez odmawianie Różańca Świętego ${ }^{50}$.

Kult ten podtrzymywany był licznymi objawieniami. Fundacja w Bieniszewie wiąże się z widzeniem, jakiego dostạpiła Zofia - służąca z pobliskiej wsi. W drodze z kościoła zobaczyła Maryję, która zapowiedziała dziewczynie, że jej życzeniem jest by w Bieniszewie osiedli kameduli. Kult Maryi w tym eremie był bardzo silny, co wiązało się zapewne także ze wspomnianym wyżej widzeniem Zofii. Kult rozrósł się jeszcze bardziej z chwilą przekazania do kościoła bieniszewskich kamedułów słynącego łaskami obrazu Maryi z Dzieciątkiem ${ }^{51}$. W Pożajściu także cieszył się kultem, łaskami słynący obraz Matki Bożej, który papież Aleksander VII przekazal fundatorowi eremu Krzystofowi Pacowi ${ }^{52}$.

\section{W Y STRÓJ}

Ustalenia wspomnianych już wcześniej kapituł generalnych nie przewidywały stosowania w kościołach kamedulskich jakichkolwiek dekoracji uważając je

${ }^{47}$ W zamyśle fundatora miały powstać jeszcze dwa kościoły (św. Marii Magdaleny i Marii Egipcjanki) poniżej eremu, przeznaczone dla kobiet.

${ }^{48}$ Pamiętniki Albrechta Stanislawa Radziwilla Kanclerza W. Litewskiego wydane z rękopisu przez Edwarda Raczyńskiego, t. 1, Poznań 1839, s. 149.

${ }^{49}$ Bielany k. Krakowa - kościół Wniebowzięcia NMP, Rytwiany - kościół Zwiastowania NMP, Bielany k. Warszawy - kościół Niepokalanego Poczęcia NMP, Bieniszew - kościól Najświętszej Panny, Poźajście - kościół Nawiedzenia NMP, Wigry - kościół Niepokalanego Poczęcia NMP.

${ }^{50}$ Konstytucje Kongregacji Pustelników ..., s. 71-72.

${ }^{51}$ Pierwotny obraz spłonął w czasie pożaru w 1741 roku. Por. W. Zaleski, Sanktuaria polskie, Warszawa 1988, s. 457.

${ }^{52} \mathrm{X}$. W a c ław z Sulgostowa [W. Nowakowski], O cudownych obrazach $w$ Polsce Przenajświętszej Matki Bożej. Wiadomości historyczne bibliograficzne i ikonograficzne, Kraków 1902, s. 543. 
za sprzeczne z duchem reguły i zachowaniem ubóstwa. Jedynymi elementami dekoracyjnymi świątyni miały być elementy architektoniczne ${ }^{53}$. W dokumentach wydanych przez kapitułę gneralna z 1610 roku można przeczytać, że zabrania się

pilastrów, ram, kapiteli i podobnych ornamentów z powodu wielkich kosztów, bo to jest przeciwne calej prostocie eremu ${ }^{54}$.

Zasady te w świątyniach kamedułów polskich nie były przestrzegane. Bodaj najokazalszym pod względem wystroju wnętrza był kościół w Pożajściu. Całe wnętrze wyłożone było

czarnym i czerwonym włoskim marmurem; takoż posadzka, kopuła zaś całkiem okryta bogatą rzeźbą i pięknymi freskami wyobrażającymi historyę zakonu Kamedułów pędzla Wlocha Delbene ${ }^{55}$.

Polichromia faktycznie (w części autorstwa także Michała Anioła Palloniego) wypełnia całą przestrzeń kościoła, wzbogacana ciekawą sztukaterią oraz elementami snycerskimi i licznymi zabytkami malarstwa ${ }^{56}$.

Równie imponująco przedstawia się kościół w Rytwianach. Całą przestrzeń światyni zdobią liczne stiuki oraz wspaniała polichromia o. Wenantego z Subiaco. Poszczególne sceny fresków na ścianach i sklepieniu ukazują wydarzenia biblijne. W medalionach pomiędzy nimi autor umieścił przedstawienia postaci dziewic i męczennic. Chór zakonny ozdabiają sceny zwiazane z życiem kamedułów. Całość dopełniają bogato zdobione stalle, których zaplecki i przedpiersia wypełniaja malowidła wzorowane na szesnastowiecznych rycinach niderlandzkich ${ }^{57}$.

W świątyni kamedulskiej na Bielanach pod Krakowem kaplice zdobią liczne stiuki na sklepieniach, które wykonal między innymi Philibert oraz obrazy autorstwa Tomasza Dolabelli i Szymona Czechowicza. Ich program ikonograficzny wiąże się głównie z życiem i działalnością świętych wywodzących się z zakonu benedyktynów i kamedułów. Ponadto można odnaleźć także sceny biblijne oraz historyczne ${ }^{58}$.

Dość mizernie na tym tle wypadaja pozostałe eremy kamedulskie na ziemiach polskich; jednak i tam jest wiele zabytków malarstwa i rzeźby, na które warto zwrócić uwagę, a które niewatpliwie wzbogacają i uświetniaja wystrój kościołów. Na przykład w kościele eremu Góry Królewskiej na uwagę zasługuje polichromia zakrystii autorstwa Michała Anioła Palloniego. W kościele w Bienisze-

${ }^{53}$ A. M a l k i e w i c z, Z historycznej i artystycznej..., s. 96.

${ }^{54}$ Cytat za: M. B r y k ow s k a, Wartości architektoniczno-przestrzenne ..., s. 55.

${ }^{55}$ F. M. S o b i e s z c zań sk i, Wiadomości historyczne o sztukach pięknych w dawnej Polsce, Warszawa 1849, s. 23.

${ }^{56}$ M. i M. F lor k o w s c y, Kameduli..., s. 330-333.

${ }^{57}$ B. U rban ow icz, Malowidła Venatego da Subiaco w Rytwianach, „Przeglad Artystyczny", nr 6:1952, s. 29-39; A. M a łk i e wi c z, Wloskie odkrycie malarstwa kameduty o. Wenantego z Subiaco, „Biuletyn Historii Sztuki”, nr 60:1998, z. 1-2, s. 213-222; J. Z u b, Rytwiany ..., s. 19-22.

${ }^{58}$ M. R o ż e k, Przewodnik po zabytkach i kulturze Krakowa. Warszawa 1993, s. 534 -541 . 
wie uwagę przykuwa ażurowy ołtarz nieznanego autorstwa $\mathrm{z}$ obrazem pięciu braci męczenników.

Wystrój kościołów kamedulskich wyróżnia jeden element - brak ambon i konfesjonałów. Mnisi nie prowadząc klasycznej działalności duszpasterskiej nie widzieli potrzeby instalowania w kościele ambony. $Z$ podobnych powodów $w$ kościolach kamedulskich nie ma organów i chórów muzycznych, przy czym w tym wypadku brak pracy duszpasterskiej nie jest jedynym powodem. W zakonie kamedułów obowiązuje bowiem zakaz śpiewu i gry na instrumentach muzycznych. W Konstytucjach zakonnych zaznaczono, że

zgodnie z dawną nasza tradycją rezygnujemy ze śpiewu liturgicznego. Podkreślamy w ten sposób granicę, jaka nas jeszcze dzieli od radości Jeruzalem niebieskiego $^{59}$.

Cechy budownictwa kamedulskiego podkreślające duchowość i tradycję Zakonu Kamedułów dostrzec można we wszystkich eremach wzniesionych na ziemiach polskich. Utrzymanie właściwie jednolitego stylu architektonicznego było moźliwe nie tylko dzięki rygorystycznym przepisom, ale i żywej tradycji. Nie znaczy to oczywiście, że wszystkie eremy kamedulskie sa identyczne. Owszem, posiadają charakterystyczne cechy wyróżniające na przykład poszczególne kościoły, jednak tradycja wznoszenia zespołów klasztornych według ,zwyczaju ojców kamedułów", przetrwał w nich przez kolejne stulecia, dając w nich poczucie ciszy, spokoju i oderwania od wszystkiego co przyziemne. Ten klimat rozmodlenia i kontemplacji Boga, jakie dawało to przedziwne i organiczne wręcz połączenie pustelni i przyrody, jest wyczuwalny nadal nawet w tych kamandolach, w których już od wielu lat nie słychać monotonnie recytowanych psalmów i szelestu kamedulskich habitów.

${ }^{59}$ Konstytucje Kongregacji Pustelników..., s.70. Por. też L. Zarewicz, Zakon Kamedutów..., s.20; J. Gajewski, Kameduli. Sztuka..., kol. 446. 


\section{Summary}

The characteristics of the Camaldolese architecture, which emphasise the spirituality and tradition of the Camaldolese Order, can be seen in all hermitages built in the territory of Poland. Keeping a mostly uniform architectural style was possible not only owing to rigorous regulations but also to the lively tradition. Naturally, this does not mean that all Camaldolese hermitages are identical. They do possess characteristic features distinguishing, for example, individual churches, however, the tradition of erecting monasteries according to the "habit of Camaldolese fathers" survived in them throughout the centuries producing an atmosphere of silence, peace and detachment from everything that is down-to-earth. This atmosphere of prayer and contemplation of God, achieved by this peculiar and nearly organic combination of a hermitage and nature, pervades today even these hermitages, in which the sound of monotonously recited psalms or the rustling of robes can no longer be heard.

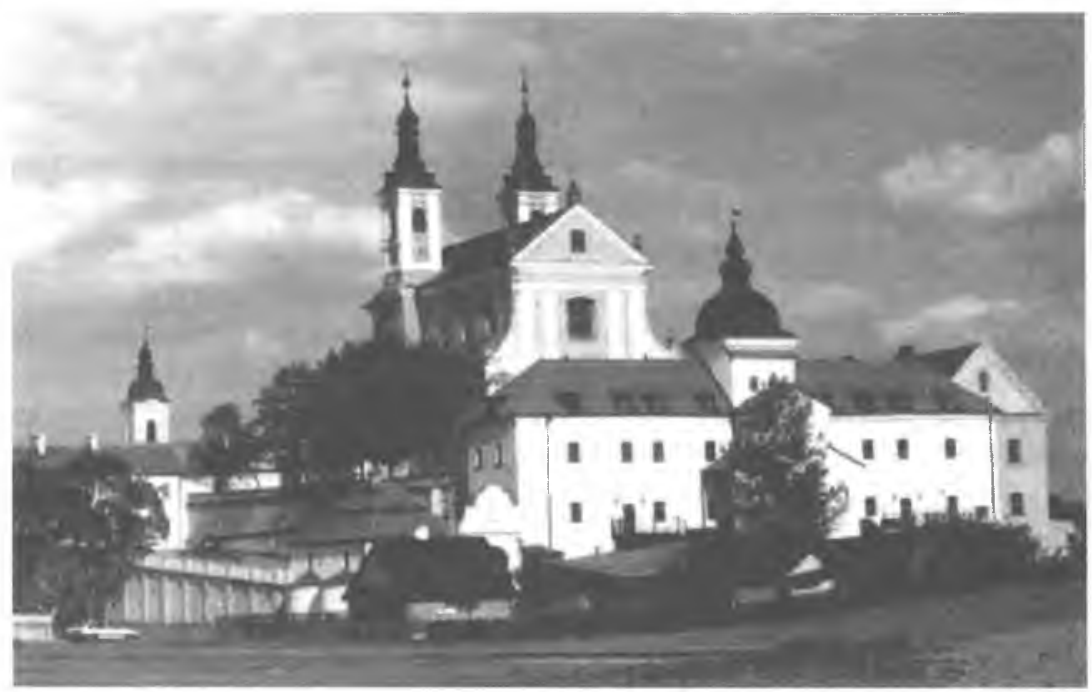

Erem kamedułów w Wigrach

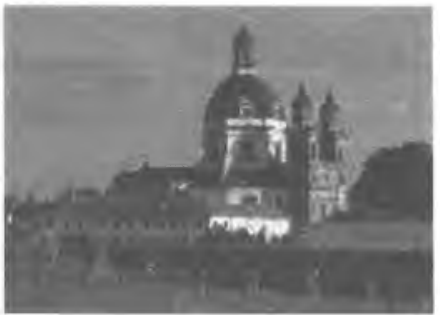

Erem Góry Pokoju w Pożajściu

Ermitorium. Bielany pod Krakowem

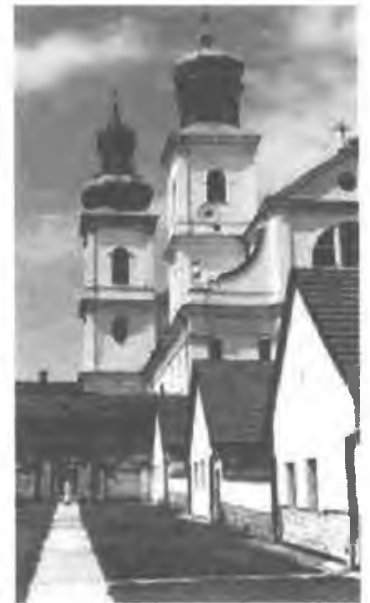




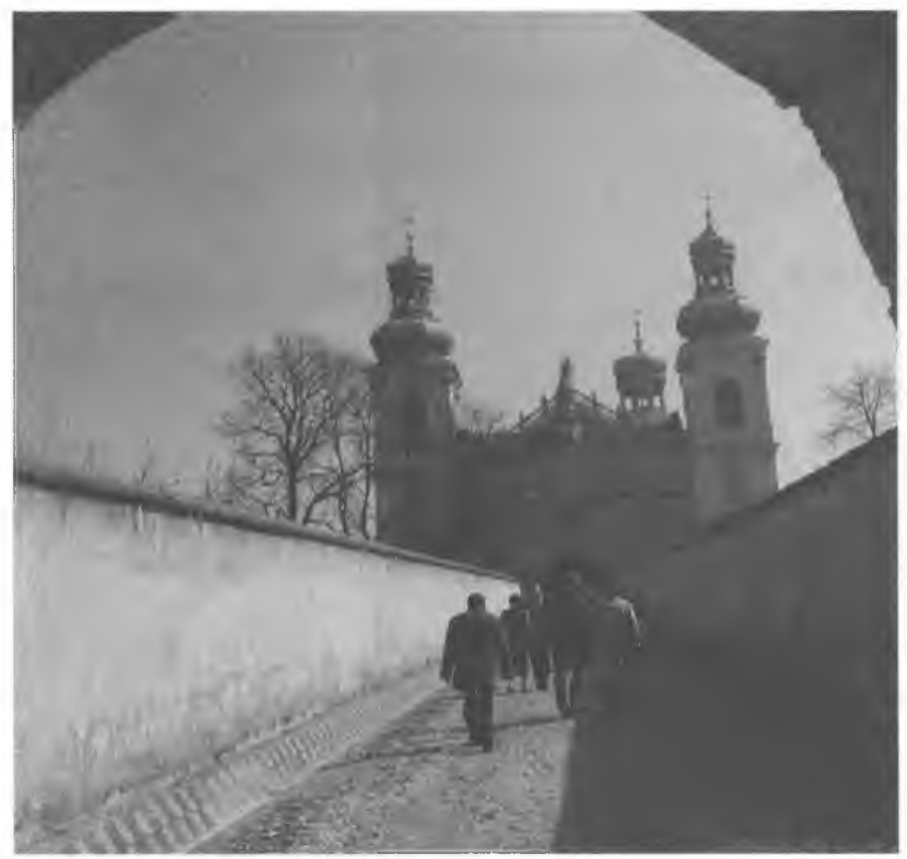

Erem Srebrnej Góry. Bielany pod Krakowem

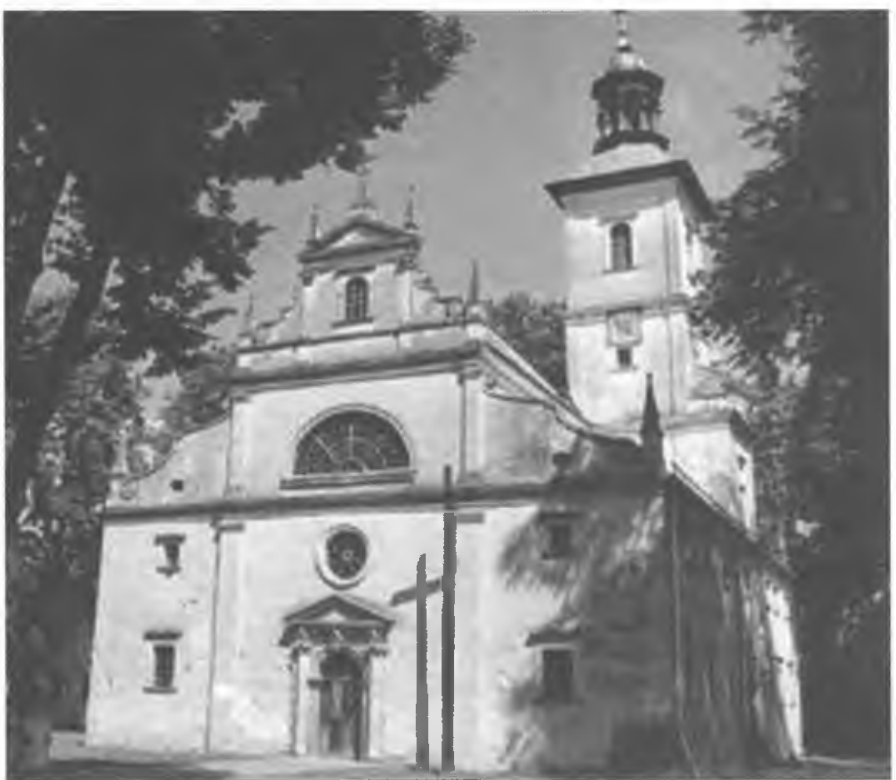

Erem Złotego Lasu w Rytwianach 


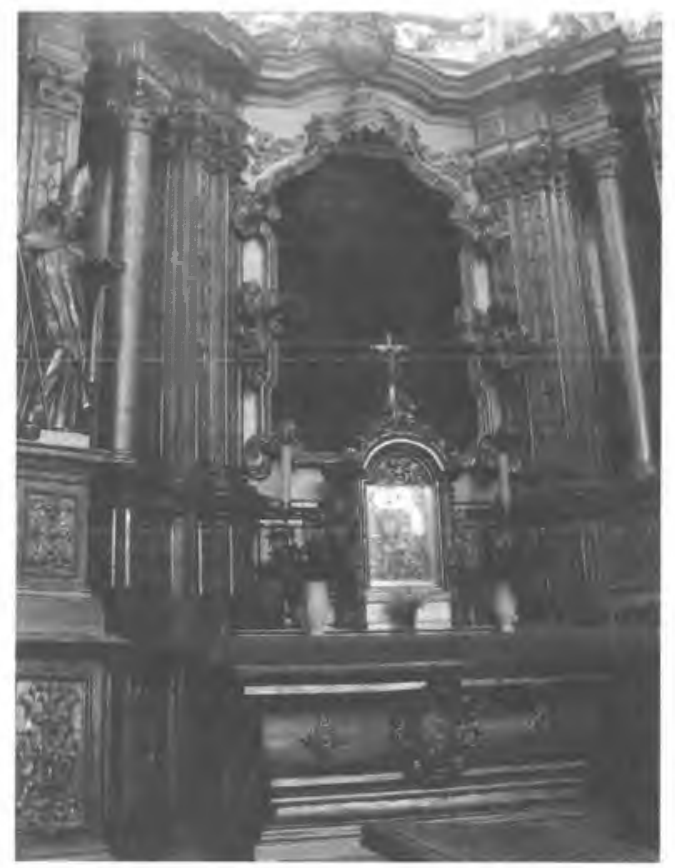

Kaplica św. Romualda.

Bielany pod Krakowem

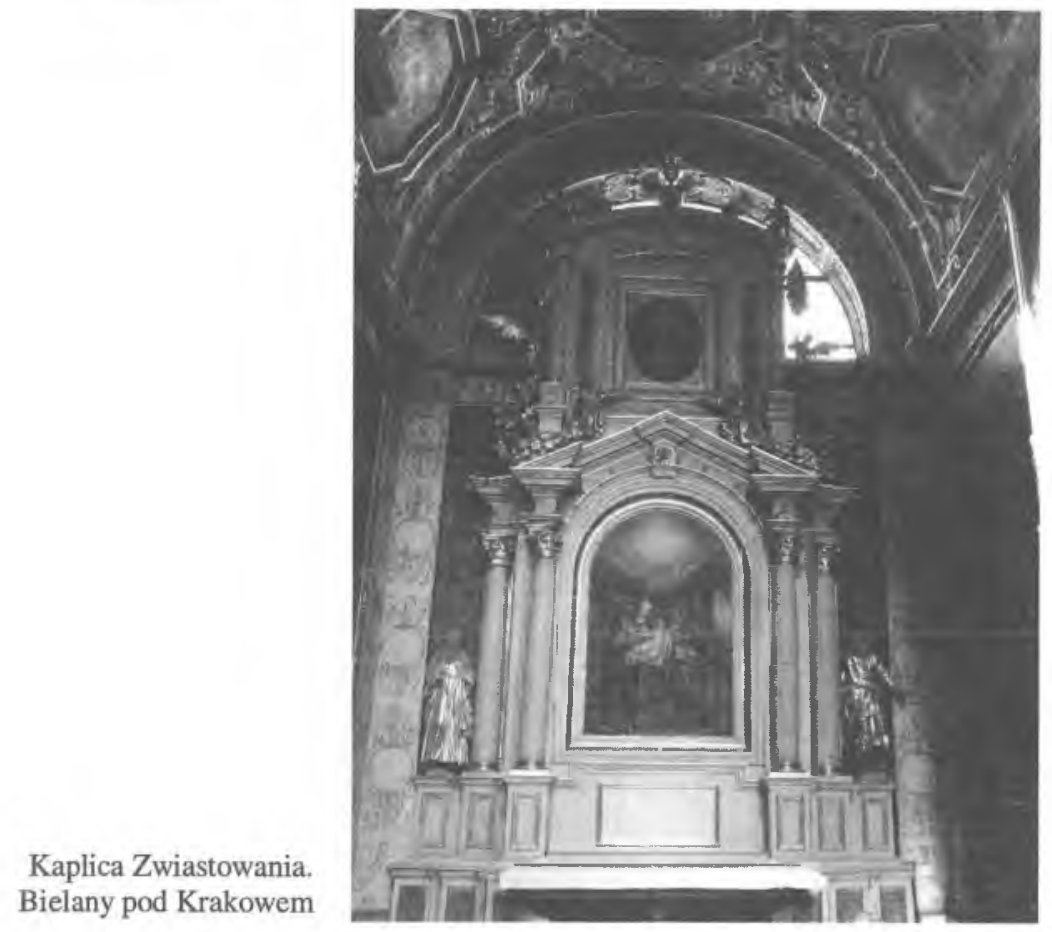




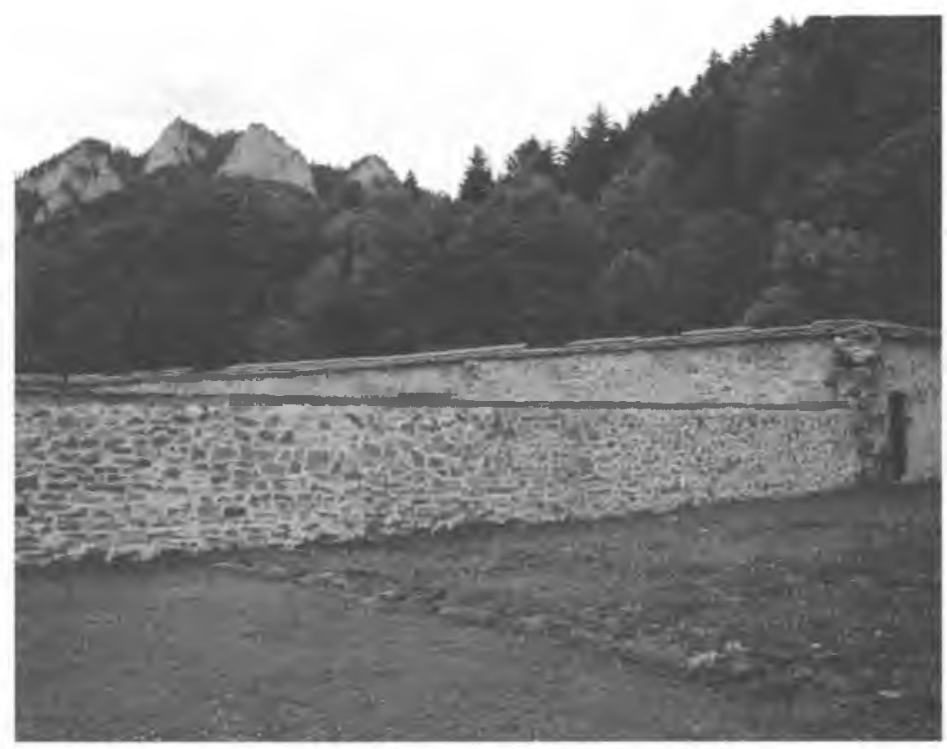

Ermitorium. Widoczny zarys fundamentów pustelni. Czerwony Klasztor

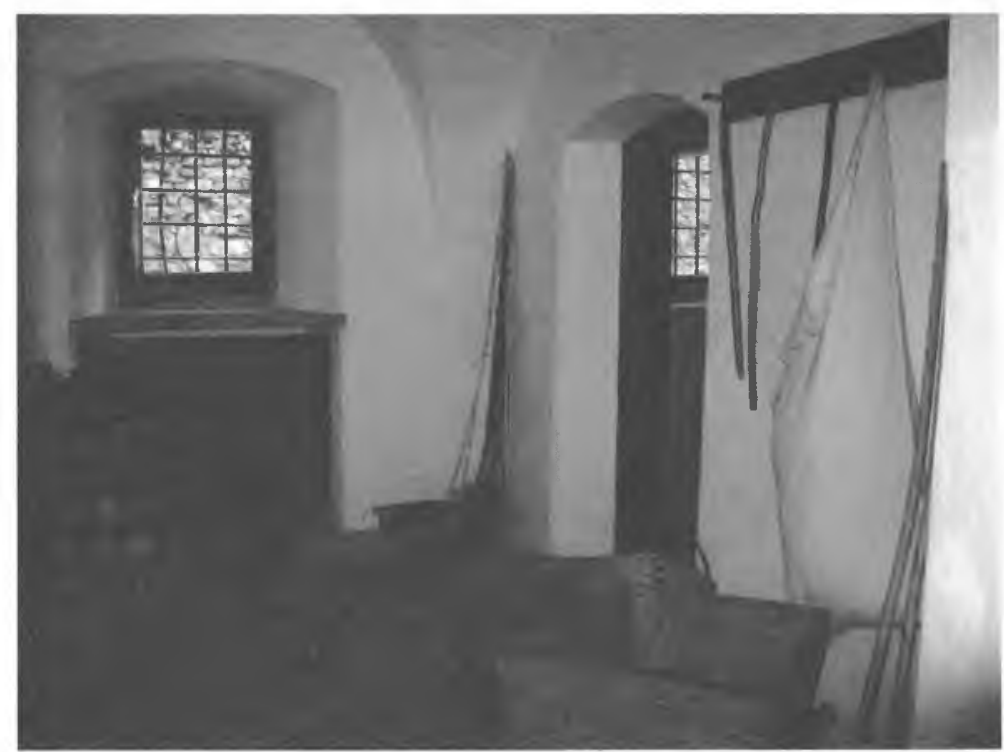

Pustelnia. Pomieszczenie gospodarcze. Czerwony Klasztor 


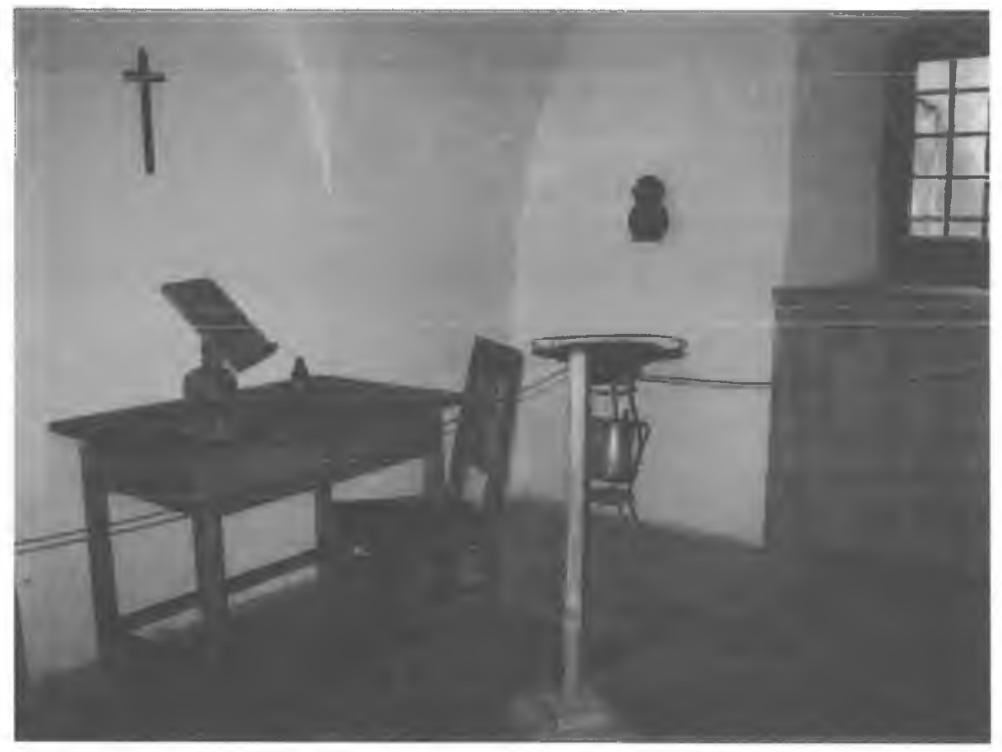

Wnętrze celi mieszkalnej. Czerwony Klasztor

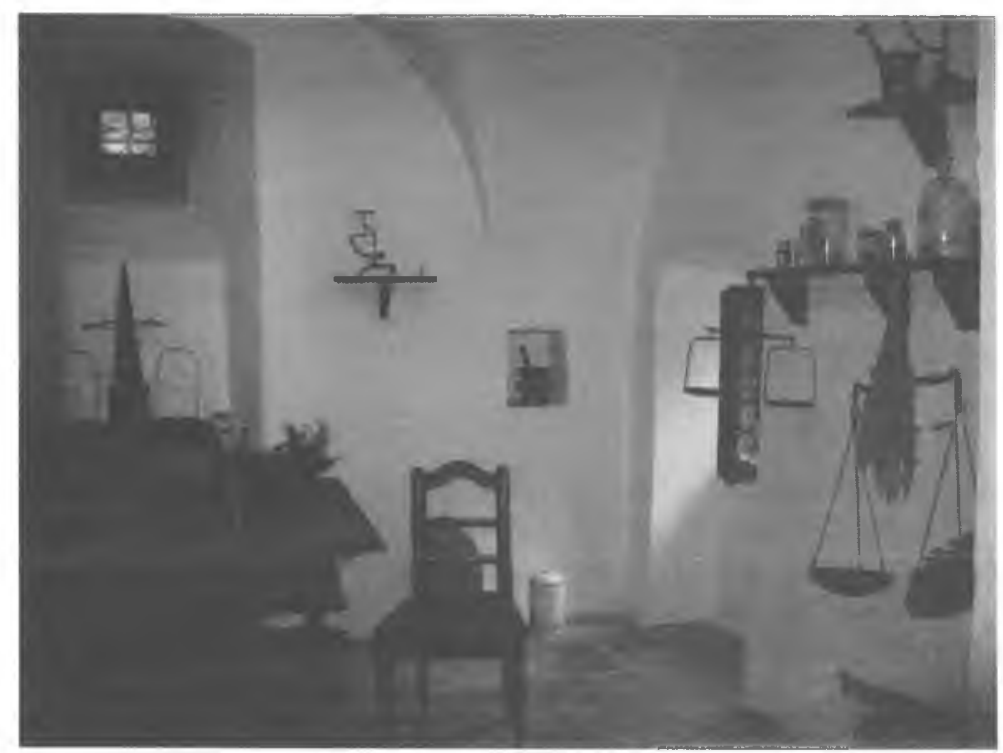

Zielarnia. Czerwony Klasztor 